\title{
Phosphorus phytoremediation using selected wetland plants in constructed floating mats
}

\author{
Katy Chapman ${ }^{1}$ (D) . Jennifer Boucher ${ }^{1}$
}

Received: 21 December 2018 / Accepted: 28 April 2020 / Published online: 25 May 2020

(c) The Author(s) 2020

\begin{abstract}
Phosphorus (P) overloading in fresh water systems has a detrimental effect by increasing the speed of eutrophication. Phytoremediation is the use of natural plants to remove contaminants from the environment. In the current study, we tested five plants (Pteris vittata, Lemna minor, Rumex orbiculatus, Rumex verticillatus, and Typha $\times$ glauca) in the laboratory and field for phosphorus mitigation potential. In the field experiment, both root and shoot phosphorus content were evaluated, and in the laboratory study percent phosphorus removed was calculated. Our research showed in both experiments that $T$. glauca removed the most phosphorus $(p<0.05)$. In the field study, shoots of $T$. glauca removed on average $3.7 \mathrm{~g} \mathrm{P} / \mathrm{plant}$, while the roots and shoots removed $12.67 \mathrm{~g}$ P/plant from water. In the laboratory study, the $T$. glauca removed $84 \%$ of the phosphorus from the water. Rumex verticillatus in both experiments had the next highest phosphorus removal rates $(0.46 \mathrm{~g} \mathrm{P} / \mathrm{shoot}$, $1.93 \mathrm{~g} \mathrm{P} /$ plant (root + shoot), and 90\% removal in the laboratory study). These results show great potential for T. glauca and $R$. verticillatus in the mitigation of phosphorus from fresh water systems.
\end{abstract}

Keywords Phytoremediation $\cdot$ Eutrophication $\cdot$ Phosphorus $\cdot$ Mediation

\section{Introduction}

Nutrient influxes in watersheds have negatively impact water quality through several mechanisms including increasing the speed of eutrophication in lakes and oceans around the world (Vincon-Leite and Casenave 2019; Istvánovics and Honti 2012; Jarvie et al. 2013). In rural Minnesota and the USA in general, this is mostly due to increased runoff from agricultural and other fertilized lands (Magner and Alexander 2008; Shoda et al. 2019). These losses not only negatively impact water quality, but also decrease soil quality resulting in increased need to fertilize which further accelerates the flow of nutrients from land to water (Khan and Ansari 2005; Magner and Alexander 2008). In freshwater systems, phosphorus is generally the limiting nutrient (Khan and Ansari 2005; Reynolds and Walsby 1975). Thus, with increased phosphorus loads eutrophication becomes a problem and ultimately decreases species diversity at many ecological

Katy Chapman

katys@crk.umn.edu

1 Math Science and Technology Department, University of Minnesota Crookston, 2900 University Ave., Crookston, MN 56716, USA levels (McJannet et al. 1995; Khan and Ansari 2005; Busman et al. 2009; Erler et al. 2011; Ke et al. 2007).

Phytoremediation is the use of plants to remove environmental pollutants from the environment (Zhang et al. 2010). Phytoremediation is a method of bioremediation that has been investigated and utilized for a broad range of contaminants including metals, organics, and radioactive contaminates (Mkandawire et al. 2004; Zhang et al. 2010). While phosphorus is a pollutant in our freshwater systems, it is also a plant nutrient, and thus the potential for phytoremediation of phosphorus is great ( Tu and Ma 2003; Benvenuti et al. 2018).

The objective of this study was to test selected plant species (Pteris vittata, Lemna minor, Rumex orbiculatus, Rumex verticillatus, and Typha $\times$ glauca) for their ability to mitigate phosphorus contamination in surface waters. Arsenic and phosphorous are very similar chemically (Tu and Ma 2003); thus, we are testing the hypotheses that the arsenic hyper-accumulating species, Pteris vittata, will take up large amounts of phosphorous compared to the other plant species in this study. The other species selected were selected for their high biomass and previous use for nutrient recovery or arsenic removal (Tu and Ma 2003; Creger and Peryea 1994; Carbonell et al. 1998; Cicek et al. 2006) as well as being

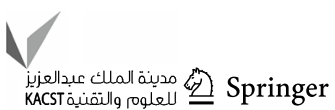


native to the field-site location with the exception of $P$. vittata which was selected due to its ability to accumulate large amounts of arsenic (Tu and Ma, 2003). Field and greenhouse studies were initiated in 2013 to evaluate these hypotheses.

\section{Materials and methods}

\section{Growth chamber study}

Young plants of Typha $\times$ glauca, Lemna minor, Rumex verticillatus, Rumex orbiculatus, and Pteris vittata were tested in this study along with an unplanted control. Lemna minor and $R$. verticillatus were obtained from Southern Tier Consulting, Inc. West Clarksville, N.Y. Young P. vittata was purchased and shipped from Edenspace Systems Corporation Manhattan, K.S. Seeds of $R$. orbiculatus were ordered from Ion Exchange, Inc. Harpers Ferry, I.A. and germinated by soaking in a $200 \mathrm{ppm}$ gibberellic acid $\left(\mathrm{GA}_{3}\right)$ solution for $48 \mathrm{~h}$ at $20^{\circ} \mathrm{C}$ (Asrar 2011). Typha $\times$ glauca were obtained locally from a agricultural containment pond. Typha $\times$ glauca were utilized when they reached approximately $30 \mathrm{~cm}$ in height. The plants were kept with $1 / 4$ strength Hoagland's solution (Hoagland and Arnon 1938; Liu and Owen 2003) prior to beginning the experiment to ensure they did not experience any nutrient deficiencies which would likely have reduced their ability to remove phosphorus from the water.

Individual plants were placed in netting on the surface of a $2 \mathrm{~L}$ mason jar. The plants were grown in $1 / 4$ strength Hoagland's solution (Hoagland and Arnon 1938; Liu and Owen 2003) with a starting phosphate concentration of $7 \mathrm{mg} / \mathrm{L}$. The jars were wrapped with aluminum foil to deter algal growth (Fig. 1). Pteris vittata, $T . \times$ glauca, $R$. verticillatus, and $R$. orbiculatus had a peat moss growth medium (Espsoma PTM8) inside the netting, whereas the L. minor floated free inside the netting. In addition to these five plant treatments, there were two unplanted controls. The first control was wet up with only the netting material (as in the L. minor treatment), and the second control was set up with the netting material and the peat moss used as a growth media for the other plant treatments.

Treatments with a peat moss growth medium had a watering tube (Watts Clear Vinyl Tubing 7/16 in OD $\times 5 / 16$ in ID North Andover, M.A.) inserted between the netting and the jar (Fig. 1) to allow watering without disruption of the growth medium. Water levels were maintained at $2000 \mathrm{~mL}$ throughout the study to ensure changes in phosphorus concentration were not due to dilution or concentration of the water. Pre-experiment water samples were taken $(50 \mathrm{~mL})$ prior to introduction of plants. After 3 months of growth, the experiment ended and post-experiment samples $(50 \mathrm{~mL})$ were taken from each Mason jar. The percent difference was then calculated for each of the experimental units. Storage and analysis of water samples are explained in Sect. 2.3.1. In the growth chamber study biomass of the plants was not recorded because the objective of the study was to determine what impact the plants were having on phosphorus concentration in the water. The controls were designed to remove any affects due to the growth medium, thus because phosphorus does not have a gas phase, we are confident phosphorus removed was removed by the plants.

The study design was a randomized complete block design with four replications. Blocks were set up along the temperature gradient in the growth chamber. The growth chamber was manufactured by Environmental Growth Chambers (2.6 $\mathrm{m}^{2}$ of growth area) (Chagrin Falls, O.H.) and was set at $21.9^{\circ} \mathrm{C}, 20 \%$ humidity, $14 \mathrm{~h}$ day $/ 10 \mathrm{~h}$ night cycle, and had a light reading of 1869 foot candles $(\mathrm{Fc})$ at the level the plants were growth $(56 \mathrm{~cm}$ from the ground). Light readings were taken with Extech instruments (Nashua, N.H.).
Fig. 1 Example of growth chamber experiment jar prior to planting. Netting material, aluminum foil and water tube are visible. The peat moss was added inside of the netting material along with plant treatments

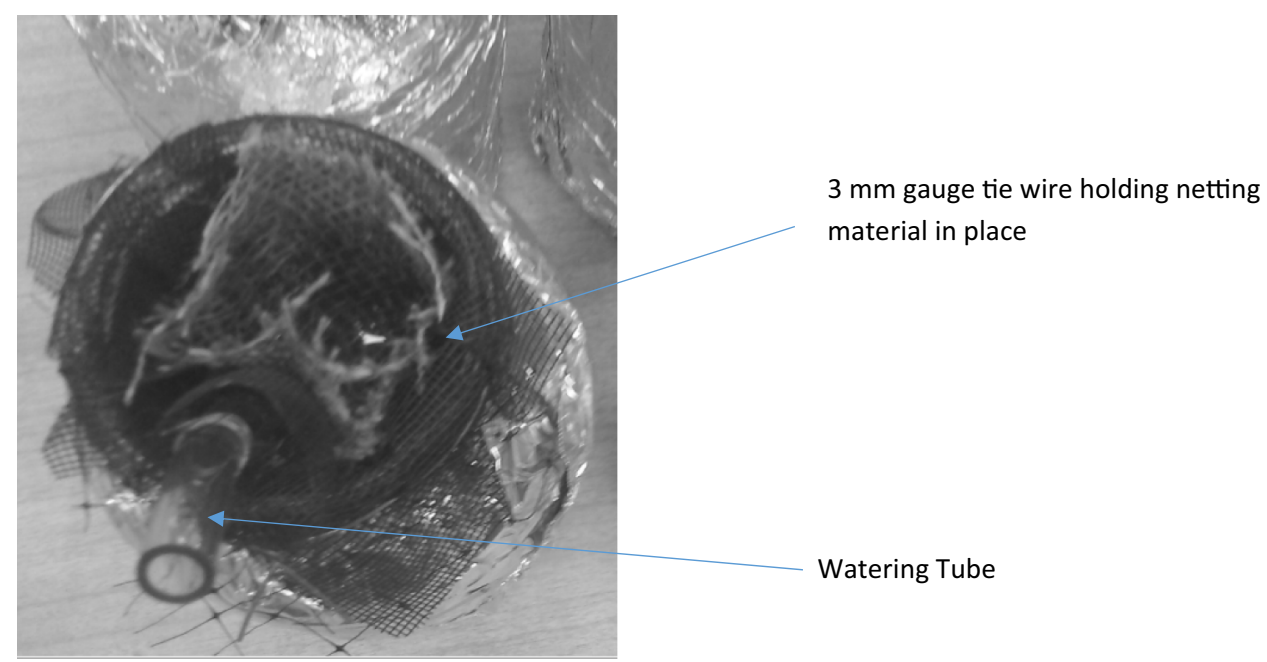




\section{Field study}

The field study was conducted on a small agricultural containment pond (1.7 hectares) at the University of Minnesota Crookston. Typha glauca, L. minor, R. verticillatus, $R$. orbiculatus, and $P$. vittata were tested in the field study. Artificially constructed floating mats were constructed using hula-hoops, floating noodles, (010POND Wildlife Netting, New York Wire Charcoal Fiberglass Screening (Hanover, P.A.), burlap, and tie wire (3 mm gauge). Netting material was used to retain peat moss used as a growth media for $T$. glauca, $R$. verticillatus, $R$. orbiculatus, and $P$. vittata (Fig. 2). Floating mats were wrapped with Polar Plastic 4-Mil Poly (Oakdale M.N.) and secured with tie wire (3 $\mathrm{mm}$ gauge) to protect the frames from wave damage (Fig. 3). Peat moss (Espsoma PTM8) was added to each of the floating mats except those with the L. minor treatment and covered with garden fabric. Two plants were placed into each floating mat. Treatments containing $L$. minor did not use a peat moss growth medium, or garden fabric, but instead had gardening rocks placed on the inside of the netting to allow the L. minor to float freely. The floating wetlands were shielded by Garden Zone ${ }^{\circledR}$ Hex Netting ( $2.5 \mathrm{~cm}$ mesh) to deter animal foraging. The field study began on June 26, 2013. The experiment ended on September 29, 2013, at which point above and below ground biomass was harvested. Plants were then separated into roots and shoots for all treatments, with the exception of $L$. minor which was maintained as a whole plant. The plant material was processed as indicated in Sect. 2.3.2. The impact of plant treatments on the concentration of phosphorus in the pond was not quantified for two reasons (1) the impact of small pilot scale plots on an entire containment pond would be insignificant and (2) all plant treatments were floating in the same containment pond.

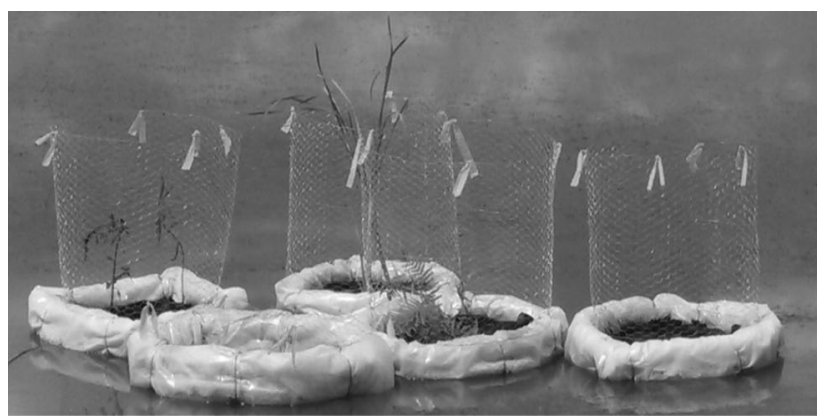

Fig. 3 One group of floating mats after planting. Fences were placed on the outside of treatments with peat moss to deter waterfowl from using the floating mats as a resting place

The study design was a randomized complete block design with four replications, with blocks set up east to west on the south side of the shore.

\section{Chemical analysis}

\section{Water}

Water samples were adjusted to a $\mathrm{pH}$ of 2 with $6 \mathrm{M} \mathrm{H}_{2} \mathrm{SO}_{4}$ and stored in $50 \mathrm{~mL}$ scintillation vials at $4{ }^{\circ} \mathrm{C}$ until analysis was conducted. Total phosphorous was determined via acid digestion of phosphate-phosphorus to orthophosphate using ascorbic acid (Method 230.1 USEPA 1997). The standards ranged from 0 to $25 \mathrm{mg} / \mathrm{L}$ and were accepted for use with $r^{2}$ values of 0.99 .

\section{Plant tissue}

The biomass was dried at $105^{\circ} \mathrm{C}$ for $72 \mathrm{~h}$, and dry weight was recorded. Biomass was then ground using standard

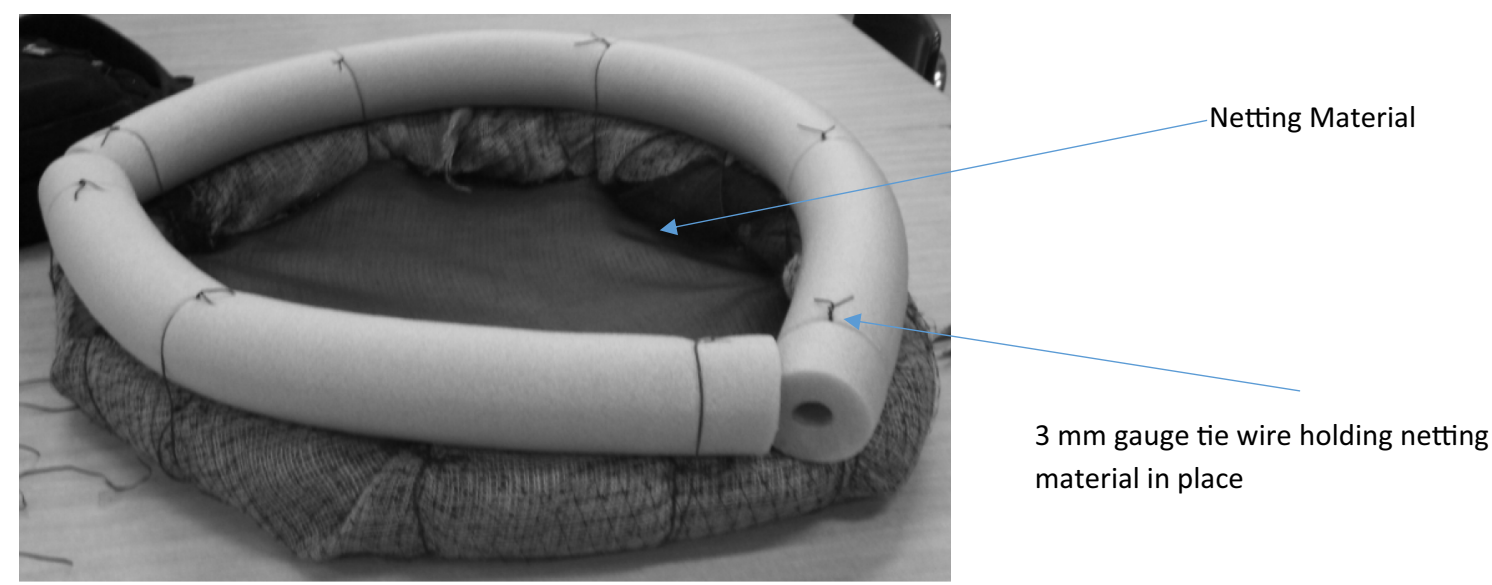

Fig. 2 Example of floating mat prior to planting. The netting material used to retain peat moss is visible on the bottom and center of the floating mat 
kitchen blenders (Scovill Hamilton Beach/14 speed Solid state Blender Southern Pines, N.C.) and sent to AGVISE Laboratories in Northwood, N.D. for total phosphorus analysis utilizing the nitric acid/hydrogen peroxide method (Zvomuya et al. 2011; Al-Hamdani and Sirna 2008) followed by quantification with an inductively coupled plasma spectrophotometer (ICP). Phosphorus removed was calculated by multiplying the concentration of phosphorous in the plant tissue by the dry weight biomass for each plant.

\section{Statistical analysis}

Data for all experiments were analyzed using the general linear model (glm) of SAS (Statistical Analysis Software, (SAS Institute, Cary, NC)). The assumptions of this model (normality, constant variance) were met in the growth chamber study, but violated in the field study. Thus, the data were transformed. Shoot phosphorus removed was transformed by $n^{-1 / 4}$, and total phosphorus removed was transformed by $n^{-3 / 4}$, where $\mathrm{n}$ is an individual data point. All graphs and data presented represent back-transformed means.

\section{Results}

\section{Laboratory study}

Statistical differences between treatments were observed (Table 1). Typha glauca (84\% removal) and $R$. verticillatus (90\% removal) removed significantly $(p<0.05)$ more phosphorus than all other plant treatments. Lemna minor (31\% removal) also removed significantly $(p<0.05)$ more phosphorus than the un-vegetated control. Rumex orbirculotus and $P$. vitata were not significantly $(p<0.05)$ different from the un-vegetated control with approximately $11 \%$ and $24 \%$ assimilated phosphorus (Table 1).

\section{Field study}

\section{Shoot analysis}

Typha glauca had phosphorus concentrations significantly $(p<0.05)$ higher than all other plant treatments with a mean mass in the shoots at approximately $3.7 \mathrm{~g} \mathrm{P} /$ plant (Table 1 ). Rumex verticillatus had significantly $(p<0.05)$ higher phosphorus removal rates $(0.46 \mathrm{~g} \mathrm{P} /$ plant $)$ than the other plant treatments in mean shoot phosphorus concentrations besides T. glauca. Rumex orbirculotus and $P$. vitata both had a mean shoot phosphorus concentration of approximately $0.12 \mathrm{~g} \mathrm{P} /$ plant (Table 1).

\section{Total plant analysis}

Above ground and below ground biomass was analyzed to find the mean total phosphorus $(\mathrm{P})$ in plant treatments. Typha glauca was found to be significantly $(p<0.05)$ higher than all other plant treatments in mean total phosphorus removed with approximately $12.04 \mathrm{~g} \mathrm{P}$ removed/plant (Table 1 ). Rumex verticillatus also had significantly $(p<0.05)$ higher phosphorus removal with $1.75 \mathrm{~g} P$ removed/plant. Rumex orbirculotus, L. minor, and $P$. vitata were not significantly different from each other. Rumex orbirculotus had a mean phosphorus concentration of $0.69 \mathrm{~g} \mathrm{P}$ removed/plant, $L$. minor had $0.62 \mathrm{~g} \mathrm{P}$ removed/plant, and $P$. vitata had a mean total of $0.51 \mathrm{~g} \mathrm{P}$ removed/plant (Table 1).

\section{Discussion}

The results of this study suggest phosphorus mitigation is possible by utilizing innovative management techniques like phytoremediation on surface waters. In the current study, T. glauca and $R$. verticillatus removed significantly more phosphorus
Table 1 Percent removal and mass removal in growth chamber and field studies

\begin{tabular}{lllllll}
\hline Species & \multicolumn{2}{l}{ Growth chamber study } & & \multicolumn{2}{l}{ Field study (back-transformed means) } \\
\cline { 2 - 3 } & \% Removed & $\begin{array}{l}\text { Mass } \\
\text { removed } \\
(\mathrm{mg})\end{array}$ & & $\begin{array}{l}\text { Mass removed by } \\
\text { shoots }(\mathrm{g})\end{array}$ & $\begin{array}{l}\text { Mass removed } \\
\text { by roots }(\mathrm{g})\end{array}$ & $\begin{array}{l}\text { Total mass } \\
\text { removed } \\
(\mathrm{g})\end{array}$ \\
\hline Typha $\times$ glauca & $84 \mathrm{a}$ & $12 \mathrm{a}$ & & $3.65 \mathrm{a}$ & $8.37 \mathrm{a}$ & $12.04 \mathrm{a}$ \\
Lemma minor & $31 \mathrm{~b}$ & $4 \mathrm{~b}$ & & $\mathrm{NA}$ & $\mathrm{NA}$ & $0.62 \mathrm{~cd}$ \\
Rumex verticillatus & $90 \mathrm{a}$ & $13 \mathrm{a}$ & & $0.45 \mathrm{~b}$ & $1.28 \mathrm{~b}$ & $1.75 \mathrm{~b}$ \\
Rumex orbirculotus & $11 \mathrm{~b}$ & $2 \mathrm{~b}$ & & $0.12 \mathrm{c}$ & $0.57 \mathrm{c}$ & $0.69 \mathrm{c}$ \\
Pteris vittata & $24 \mathrm{~b}$ & $3 \mathrm{~b}$ & & $0.12 \mathrm{c}$ & $0.39 \mathrm{~d}$ & $0.51 \mathrm{~d}$ \\
\hline
\end{tabular}

Within columns; means represented by statistically significant differences $(p<0.05)$ have different letters following the numerical value
(ئ) مدينة الملك عبدالعزيز

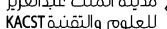


(P) than all other treatments. Typha glauca removed on average $3.7 \mathrm{~g} \mathrm{P} /$ shoot and $12.67 \mathrm{~g} \mathrm{P} /$ plant (root + shoot) (Table 1). Similar findings have been reported in the literature, Garver et al. (1988) found that T. glauca accumulated at its peak $3.9 \mathrm{~g}$ $\mathrm{P} / \mathrm{m}^{2}$ of soil $(0.46 \mathrm{~g} \mathrm{P} /$ plant vs. $12.67 \mathrm{~g} \mathrm{P} /$ plant found in the current study), while Martin and Fernandez (1992) reported $1.3 \mathrm{~g} \mathrm{P} /$ plant removed. In these studies and others (Cicek et al. 2006; Maddison et al. 2009) the reported phosphorus content per plant is much lower than found in the current study; however, in these studies the plants were grown in soil which would have a lower available phosphorus concentration than the water used in the current study. Phosphorus in soil is not available for plant uptake until it enters the solution phase of the soil; thus, the total concentration of phosphorus present could be identical, but the plant available phosphorus would be much lower in the experiments conducted in soil (Tu and Ma 2003; Wang et al. 2002).

Cicek et al. (2006) conducted a study evaluating potential removal of phosphorus from different plant species. When these authors used the percent phosphorus in various species along with the published yearly biomasses of the selected plant species, they concluded that $T$. glauca was one of the best performers in phosphorus removal. This is consistent with our results in that we found $T$. glauca to be the most effective species for phosphorus removal, although not always significantly more effective than $R$. verticillatus. McJannet et al. (1995) compared 41 wetland species dry weight percent phosphorus and found that $R$. verticillatus had $1.07 \%$ phosphorus, and T. glauca had around $0.3 \%$ phosphorus. The current study found $0.09 \%$ total phosphorus in T. glauca biomass which is lower than some of the other plant treatments used in this study. Although T. glauca didn't have the highest percent phosphorus, it did have the highest dry weight biomass out of all the selected plant treatments. Thus the total phosphorus removed in T. glauca was the highest. Our results are consistent with the range of values reported in previous studies (McJannet et al. 1995; Cicek et al. 2006; Maddison et al. 2009).

In our study, $T$. glauca removed significantly $(p<0.05)$ more phosphorus than all other treatments when only the shoots were harvested (3.64 g P/shoot) and also when the entire plant was removed (12.04 g P/plant) (Table 1). Interestingly, removing the entire plant increased the total phosphorus removal by nearly fourfold. Removing root and shoot biomass is detrimental to overall stand health, making it less desirable to wildlife (Dubbe et al. 1988; Cicek et al. 2006; Garver et al. 1988). In addition, this practice would require specialized rhizome harvesting machinery (Dubbe et al. 1988); however, the ease of rhizome removal in floating mats makes rhizome harvesting more feasible.

Phosphorus removal capabilities between Rumex spp. have not been reported in the literature, but in the current study phosphorus accumulation range varied significantly between the two Rumex spp. (R. verticillatus removing $1.93 \mathrm{~g} \mathrm{P} /$ plant and $R$. orbirculotus removing $0.73 \mathrm{~g} \mathrm{P} / \mathrm{plant}$ ) (Table 1) indicating there are significant differences in phosphorus removal potential within species of the same genus.

One of the hypotheses driving this study was that the arsenic-hyperaccumulator, $P$. vittata would be able to take up large amounts of phosphorous relative to the other species in this study. However, in the current study $P$. vittata had one of the lowest phosphorus removal rates of all the plant treatments (0.51 g P/plant). Tu and Ma (2003) found phosphorus concentrations ranging from 0.06 to $0.08 \mathrm{~g} \mathrm{P} /$ plant. Tu and Ma (2003) grew $P$. vittata in soil with low phosphorus concentrations (0.025-0.099 g P), thus causing low phosphorus accumulation by the plant. $P$. vittata in the current study showed signs of light stress (shriveled leaves), thus providing shade for the plant may change the results. However, our results do not support utilizing arsenic-hyperaccumulators for phosphorus mitigation.

The last species to be evaluated in this study is $L$. minor, which had a moderate phosphorus accumulation rate of $0.62 \mathrm{~g} \mathrm{P} /$ plant (Table 1). Our findings are similar to that found throughout the literature. Wang et al. (2002) tested $L$. minor at different phosphorus concentrations with the highest being $31 \mathrm{mg} \mathrm{P} / \mathrm{L}$ which resulted in the plants accumulating $0.35 \% \mathrm{P}$. In the current study, phosphorus concentration was approximately $5 \mathrm{mg} \mathrm{P} / \mathrm{L}$, but $L$. minor had a concentration of $0.35 \% \mathrm{P}$ in its biomass. This suggests that L. minor reaches its maximum phosphorus accumulation around $0.35 \% \mathrm{P}$. Fredric et al. (2006) studied the effects of mat density on duckweed and found that at optimal growing conditions $L$. minor assimilated $0.128 \mathrm{~g} \mathrm{P} / \mathrm{m}^{2}$ water surface area per day. This is similar to the current study with $L$. minor having an average removal of $0.115 \mathrm{~g} \mathrm{P} / \mathrm{m}^{2}$ water surface area per day. The current study along with the reviewed literature suggests that less frequent harvesting of L. minor would not harm phosphorus mitigation (Fredric et al. 2006). This is likely because the L. minor will continue to propagate as long as the phosphorus levels in the water support their growth.

\section{Conclusion}

The data show that phosphorus uptake among plant species differs and that some plant species store higher concentrations of phosphorus in their tissues. Typha glauca mitigates phosphorus to a greatest extent of the species studies in the current study. Rumex verticillatus also accumulated large amounts of phosphorus in the current study, but more research should be conducted on Rumex spp. to fully grasp this genus's capabilities. The current study suggests utilizing innovative management techniques like phosphorus phytoremediation is possible and could be a green solution to the growing problem of phosphorus contamination of 
our waterways. Investigating phosphorus phytoremediation capabilities in native perennial species could increase the utility of this technique.

Acknowledgements Funding for this project was provided by the Undergraduate Research Opportunities Program (UROP) and the University of Minnesota Northwest Regional Sustainable Development Partnership. Technical assistance by Tim Baker and Paul Lewin.

\section{Compliance with ethical standards}

Conflict of interest The authors declare that they have no conflict of interest.

Open Access This article is licensed under a Creative Commons Attribution 4.0 International License, which permits use, sharing, adaptation, distribution and reproduction in any medium or format, as long as you give appropriate credit to the original author(s) and the source, provide a link to the Creative Commons licence, and indicate if changes were made. The images or other third party material in this article are included in the article's Creative Commons licence, unless indicated otherwise in a credit line to the material. If material is not included in the article's Creative Commons licence and your intended use is not permitted by statutory regulation or exceeds the permitted use, you will need to obtain permission directly from the copyright holder. To view a copy of this licence, visit http://creativecommons.org/licenses/by/4.0/.

\section{References}

Al-Hamdani SH, Sirna CB (2008) Physiological responses of Salvina minima to different phosphorus and nitrogen concentrations. Am Fern J 98:71-82

Asrar AA (2011) Seed germination induction of hommaidh (Rumex vesicarius $\mathrm{L}$.) by gibberellic acid and temperature applications. Agric Environ Sci 10:310-317

Benvenuti T, Hamerski F, Giacobbo A, Bernardes AM, Zoppas-Ferreira J, Rodrigues MA (2018) Constructed floating wetland for the treatment of domestic sewage: a real-scale study. Environ Chem Eng 6(5):5706-5711

Busman L, Lamb J, Randall G, Rehm G, Schmitt M (2009) Nutrient management: the nature of phosphorus in soils. University of Minnesota Extension

Carbonell AA, Aarabi MA, Delaune RD, Gambrell RP, Patric WH Jr (1998) Arsenc in wetland vegetation: availability, phytotoxicity, uptake and effects on plant growth and nutrition. Sci Total Environ 217:189-199

Cicek N, Lambert S, Venema HD, Snelgrove KR, Bibeau EL, Grosshans R (2006) Nutrient removal and bio-energy production from Netley-Libau Marsh at Lake Winnipeg through annual biomass harvesting. Biomass Bioenergy 30:529-536

Creger TL, Peryea FJ (1994) Phosphate fertilizer enhances arsenic uptake by apricot liners grown in lead-arsenic-enriched soil. HortScience 29:88-92

Dubbe DR, Garver EG, Pratt DC (1988) Production of cattail (Typha spp.) biomass in Minnesota, USA. Biomass 17:79-104

Erler DV, Tait D, Eyre BD, Bingham M (2011) Observations of nitrogen and phosphorus biogeochemistry in a surface flow constructed wetland. Sci Total Environ 409:5359-5367

Fredric M, Samir L, Louise M, Abdelkrim A (2006) Comprehensive mondeling of mat density effect on duckweed (Lemna minor) growth under controlled eutrophication. Water Res 40:2901-2910
Garver EG, Dubbe DR, Pratt DC (1988) Seasonal patterns in accumulation and partitioning of biomass and macronutrients in Tyhpa spp. Aquat Bot 32:115-127

Hoagland DR, Arnon DI (1938) The water-culture method for growing plants without soil. Univ Calif Agric Res Stn Circ 347:1-39

Istvánovics V, Honti M (2012) Efficiency of nutrient management in controlling eutrophication of running waters in the Middle Danube Basin. Hydrobiologia 686:55-71

Jarvie HP, Sharpley AN, Withers PJ, Scott JT, Haggard BE, Neal C (2013) Phosphorus mitigation to control river eutrophication: murky waters, inconvenient truths, and "postnormal" science. J Environ Qual 42(2):295-304

Ke W, Xiong Z, Chen S, Chen J (2007) Effect of copper and mineral nutrition on growth, copper accumulation and mineral element uptake in two Rumex japonicus populations from a copper mine and an uncontaminated field sites. Eviron Exp Bot 59:59-67

Khan FA, Ansari AA (2005) Eutrophication: an ecological vision. Bot Rev 71:449-482

Liu MC, Owen MDK (2003) Effect of seed reserve utilization on woolly cupgrass (Eriochloa villosa) development. Weed Sci 51:78-82

Maddison M, Mauring T, Remm K, Lesta M, Mander U (2009) Dynamics of Typha latifolia L. populations in treatment wetlands in Estonia. Ecol Eng 35:258-264

Magner J, Alexander S (2008) Drainage and nutrient attenuation in a riparian interception-wetland: southern Minnesota, USA. Environ Geol 54:1367-1376

Martin I, Fernandez J (1992) Nutrient dynamics and growth of a cattail crop (Typha latifolia L.) developed in an effluent with high eutrophic potential-application to wastewater purification systems. Biores Technol 42:7-12

McJannet CL, Keddy PA, Pick FR (1995) Nirtogena and phosphorus tissue concentrations in 41 wetland plants: a comparison across habitats and functional groups. Funct Ecol 9:231-238

Mkandawire M, Taubert B, Dudel EG (2004) Capacity of Lemna gibba L. (Duckweed) for uranium and arsenic phytoremediation in mine tailing waters. Int J Phytoremediat 6:347-362

Reynolds CS, Walsby AE (1975) Water-blooms. Biol Rev 50:437-481

Shoda ME, Sprague LA, Murphy JC, Riskin ML (2019) Water-quality trends in U.S. rivers, 2002 to 2012: relations to levels of concern. Sci Total Environ 650(Part 2):2314-2324

Tu C, Ma LQ (2003) Effects of arsenate and phosphate on their accumulation by an arsenic-hyperaccumulator Pteris vittata L. Plant Soil 249:373-382

USEPA (1997) Method LMMB 062: ESS method 230.1: total phosphorus and total kjeldahl nitrogen, semi-automated method, Lake Michigan mass balance study methods compendium, volume 3: metals, conventionals, radio chemistry, and biomonitoring sample analysis techniques. EPA 905-R-97-012c. Great Lakes National Program Office, U.S. Environmental Protection Agency, Chicago, IL

Vincon-Leite B, Casenave C (2019) Modelling eutrophication in lake ecosystems: a review. Sci Total Environ 651:2985-3001

Wang Q, Cui Y, Dong Y (2002) Phytoremediation of polluted waters potentials and prospects of wetland plants. Acta Biotechnol 22:199-208

Zhang BY, Zheng JS, Sharp RG (2010) Phytoremediation in engineered wetlands: mechanisms and applications. Procedia Environ Sci 2:1315-1325

Zvomuya F, Larney FJ, Willms WD, Beck RK, Olson AF (2011) Vegetation response to a one-time spent drilling mud application to semiarid, mixed-grass prairie. Rangel Ecol Manag 64:375-383

Publisher's Note Springer Nature remains neutral with regard to jurisdictional claims in published maps and institutional affiliations. 